\title{
Development of an Empty Sella in Neurosarcoidosis
}

\author{
Arshpreet Kaur ${ }^{1 *}$, Pankaj Sharma ${ }^{2}$, Zeng Wang ${ }^{2}$, Charles E Moore ${ }^{3}$, Mary Koutourousiou ${ }^{4}$, Aly Abayazeed $^{5}$, \\ Robert Bert ${ }^{5}$ and Stephen J Winters ${ }^{1}$
}

${ }^{1}$ Division of Endocrinology, Metabolism and Diabetes, University of Louisville, USA

${ }^{2}$ Department of Neurology, University of Louisville, USA

${ }^{3}$ Division of Rheumatology, University of Louisville, USA

${ }^{4}$ Department of Neurosurgery, University of Louisville, USA

${ }^{5}$ Department of Radiology, University of Louisville, USA

Submission: February 09, 2017; Published: March 28, 2017

*Corresponding author: Arshpreet Kaur, MBBS, 2435 West Belvedere Avenue, Suite \#56, Sinai Hospital of Baltimore, Baltimore, MD -21215, USA, Tel: 443-642-7607; Email: arshpreet.31@gmail.com

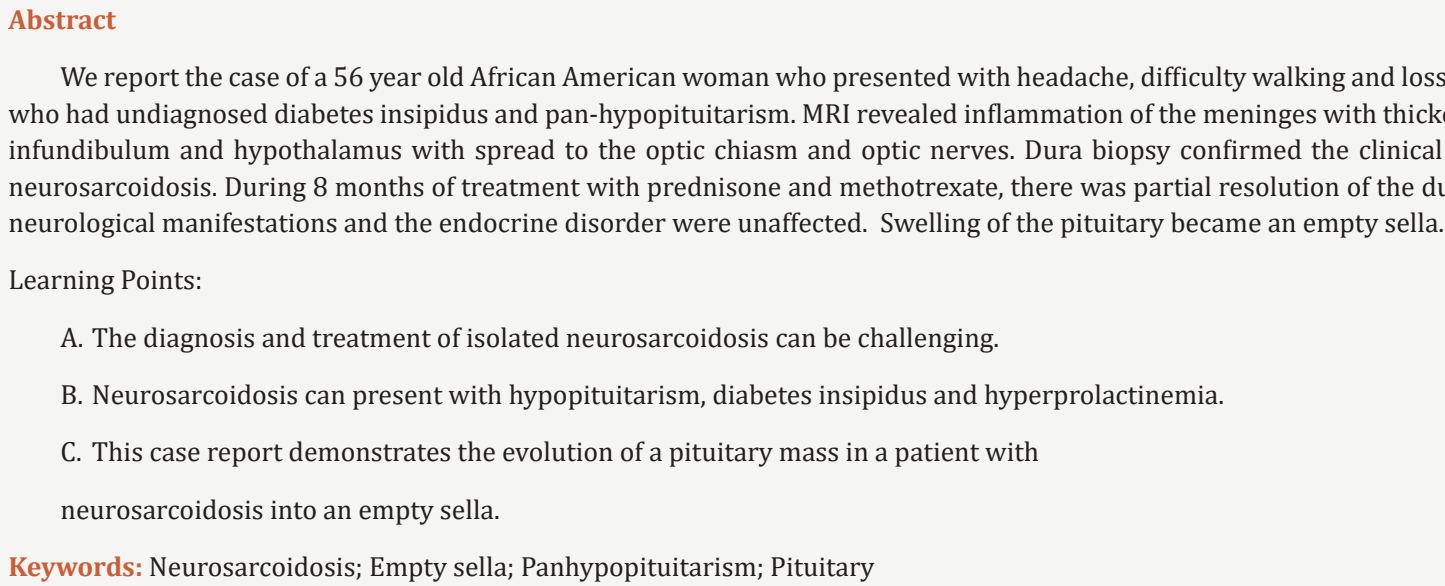
neurological manifestations and the endocrine disorder were unaffected. Swelling of the pituitary became an empty sella.

Learning Points:

A. The diagnosis and treatment of isolated neurosarcoidosis can be challenging.

B. Neurosarcoidosis can present with hypopituitarism, diabetes insipidus and hyperprolactinemia.

C. This case report demonstrates the evolution of a pituitary mass in a patient with

neurosarcoidosis into an empty sella.

Keywords: Neurosarcoidosis; Empty sella; Panhypopituitarism; Pituitary

We report the case of a 56 year old African American woman who presented with headache, difficulty walking and loss of hearing and vision who had undiagnosed diabetes insipidus and pan-hypopituitarism. MRI revealed inflammation of the meninges with thickening of the pituitaryinfundibulum and hypothalamus with spread to the optic chiasm and optic nerves. Dura biopsy confirmed the clinical diagnosis of isolated neurosarcoidosis. During 8 months of treatment with prednisone and methotrexate, there was partial resolution of the dura thickening but the

\section{Introduction}

An empty sella develops when arachnoid herniates into the sellaturcica through a congenital or acquired defect in the dura, and cerebrospinal fluid (CSF) fills the sella and compresses the pituitary gland. Radiologically, the expanded sella is defined as partially empty if less than $50 \%$ is filled with CSF and the pituitary gland thickness is $\geq 3 \mathrm{~mm}$, or total, when more than $50 \%$ of the sella is filled with CSF and the gland thickness is $\leq$ $2 \mathrm{~mm}$. A partial empty sella is a common radiographic finding, and is usually asymptomatic, and found incidentally. Endocrine deficiencies may occur, but are much more common in total empty sella [1].

Empty sella is also divided into two groups clinically, primary and secondary. Patients with primary empty sella are more often female and overweight [2], and some have idiopathic intracranial hypertension [3]. An empty sella may also develop following pituitary injury. Disorders associated with secondary empty sella include wrents in the diaphramatasella, pituitary macroadenomas treated surgically or by radiotherapy or following the spontaneous necrosis of pituitary apoplexy, Sheehan's syndrome, vasculitis, infection, head trauma, and autoimmune hypophysitis. In several cases, a pituitary mass, believed to represent autoimmune hypophysitis, was documented to convert to an empty sella [4]. For neurosarcoidosis, there are case reports of empty sella by CT [5] and pneumoencephalogram [6] but the condition is rarely mentioned among the causes of empty sella. This case report demonstrates the evolution of a pituitary mass in a patient with neurosarcoidosis into an empty sella. 


\section{Case Report}

A 56 year-old African American woman with hypertension presented with progressive bilateral vision loss, difficulty walking, vertigo, headache, hearing loss, extreme polyuria and polydipsia, and a $20 \mathrm{lb}$ weight loss over 4 months. She had deficits in cranial nerves II, VII and VIII, and a wide based gait.

\section{Results}

Endocrine tests indicated pan-hypopituitarism: LH 0.2IU/L (reference range in menopause 13.1-86.5), FSH 1.0IU/L (reference range in menopause $21.5-131$ ), free $\mathrm{T} 40.35 \mathrm{ng} / \mathrm{dL}$ (reference range $0.78-2.19$ ), TSH $0.44 \mathrm{mU} / \mathrm{L}$ (reference range $0.46-4.68$ ), GH $0.2 \mathrm{ng} / \mathrm{ml}$ (reference range <10), IGF-1 118ng/ $\mathrm{ml}$ (reference range 50-317; -1.4 SD for age), IGF-BP3 2.5mg/L (reference range 3.4-6.9), A.M. cortisol $0.83 \mu \mathrm{g} / \mathrm{dL}$ (reference range 4.5-22.7), and ACTH $6 \mathrm{pg} / \mathrm{mL}$ (reference range 6-50). The PRL level was increased at $56 \mathrm{ng} / \mathrm{mL}$ (reference range $3.0-18.6$ ). The plasma osmolality was $290 \mathrm{m0sm} / \mathrm{kg}$ while the urine osmolality was $236 \mathrm{mOsm} / \mathrm{kg}$ which rose to $827 \mathrm{mOsm} /$ $\mathrm{kg}$ following dDAVP, consistent with central diabetes insipidus. Magnetic Resonance Imaging (MRI) revealed diffuse dural thickening, pituitary enlargement and mild leftward deviation of the pituitary stalk (Figure 1A). The level of angiotensin converting enzyme in serum 40U/L (reference range 9-67) and CSF $4 \mathrm{U} / \mathrm{L}$ (reference range $<15$ ) was normal. Dural biopsy showed both non-caseating and caseating granulomas with focal scanty necrosis. Chest CT was normal. Isolated neurosarcoidosis was diagnosed after extensive testing to exclude infection and malignancy. She was treated with prednisone and methotrexate as well as levothyroxine and desmopressin. A repeat MRI after 8 months revealed partial resolution of the dura thickening and an empty sella (Figure 1).

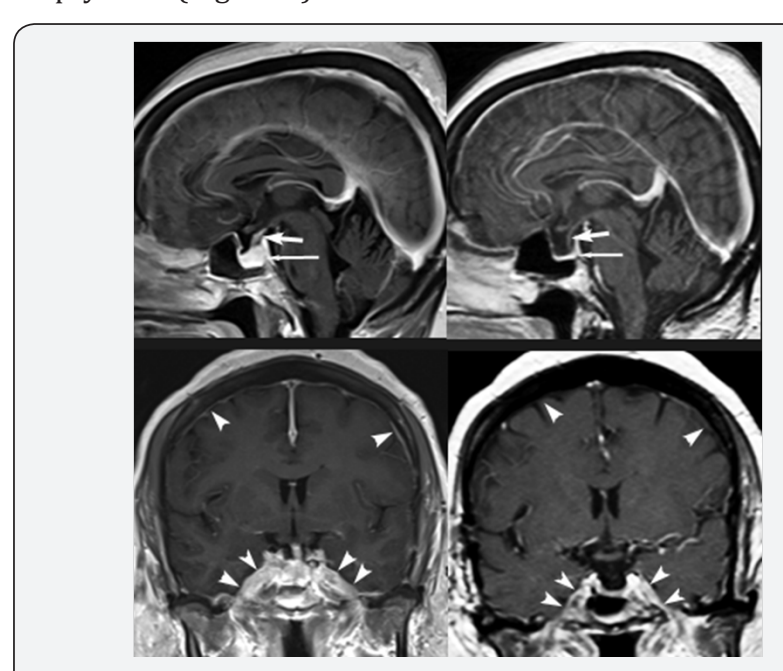

Figure 1: Sagittal and coronal contrast-enhanced pre-treatment $(A, C)$ and post-treatment $(B, D)$ T1-weighted images. Pretreatment, infundibulum (short arrows) is thickened and the pituitary gland (long arrows) is enlarged. Pachymeninges (arrowheads) abnormally enhances. Post-treatment, all of these changes have regressed. A partial empty sella pattern remains.

\section{Outcome and follow-up}

With treatment, her weight increased $37 \mathrm{~kg}$, her neurological symptoms were unchanged, and pan-hypopituitarism and diabetes insipidus persisted. She continued to complain of polydipsia and polyuria even when the urine specific gravity was maintained at 1.018. After 12 months of treatment, methotrexate was stopped, and prednisone was slowly reduced to a maintenance dose, with addition of azathioprine for steroid sparing.

\section{Discussion}

Sarcoidosis is a multisystem inflammatory disorder that is defined by the histological finding of noncaseating granulomas. While the disorder can affect any organ, the lung, liver, eye and skin are most commonly involved. The nervous system is affected in $5-14 \%$ of cases, which may occur in isolation [7]. Patients with neurosarcoidosis may present with partial or complete anterior hypopituitarism, diabetes insipidus (DI), and hyperprolactinemia [8]. Excess thirst and polyuria may also occur without DI [9]. The diagnosis of isolated neurosarcoidosis can be challenging, as it can present with a wide variety of symptoms and imaging findings $[9,10]$. Involvement of the leptomeninges can be diffuse, focal or multifocal. The brain parenchyma and spinal cord may be affected, and in some cases the MRI appears normal. Basilar leptomeningeal disease can involve the cranial nerves and the hypothalamus-pituitary unit where the differential diagnosis includes lymphocytic hypophysitis, histiocytosis, tuberculosis, leukemia and metastasis. Measurement of the angiotensin converting enzyme level in serum and CSF is rarely helpful [11], and biopsy is needed for definitive diagnosis. Neurosarcoidosis patients are generally treated with high dose corticosteroids and immunosuppressive agents, and while the neurosarcoid lesions may regress, endocrine dysfunction is usually irreversible [8]. This case demonstrates that empty sella can be the direct outcome of sarcoidosis affecting the pituitary.

\section{Funding}

This research was not supported by a grant from any funding agency in the public, commercial or not-for-profit sector.

\section{References}

1. Zuhur SS, Kuzu I, Ozturk FY, Uysal E, Altuntas Y (2014) Anterior pituitary hormone deficiency in subjects with total and partial primary empty sella: do all cases need endocrinological evaluation? Turk Neurosurg 24(3): 374-379.

2. Guitelman M, Garcia Basavilbaso N, Vitale M, Chervin A, Katz D, et al (2013) Primary empty sella (PES): a review of 175 cases. Pituitary 16(2): 270-274.

3. Bidot S, Saindane AM, Peragallo JH, Bruce BB, Newman NJ, et al. (2015) Brain Imaging in Idiopathic Intracranial Hypertension. J Neuro ophthalmol 35(4): 400-411.

4. Nakasone Y, Oguchi K, Sato Y, Okubo Y, Yamauchi K, et al. (2015) Rapid conversion of autoimmune hypophysitis to an empty sella with immediate lowering of the serum IgG4 level. Case Report. Neuro Endocrinol Lett 36(2): 112-114. 
5. Chiang R, Marshall MC, Rosman PM, Hotson G, Mannheimer E, et al. (1984) Empty sellaturcica in intracranial sarcoidosis. Pituitary insufficiency, primary polydipsia, and changing neuroradiologic findings. Arch Neurol 41(6): 662-665.

6. Lee FK, Richter HA, Tsai FY (1976) Secondary empty sella syndrome. Acta Radiol Suppl 347: 313-326.

7. Porter N, Beynon HL, Randeva HS (2003) Endocrine and reproductive manifestations of sarcoidosis. QJM 96(8): 553-561.

8. Langrand C, Bihan H, Raverot G, Varron L, Androdias G, et al. (2012) Hypothalamo-pituitary sarcoidosis: a multicenter study of 24 patients. QJM 105(10): 981-995.

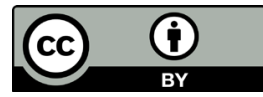

This work is licensed under Creative Commons Attribution 4.0 Licens

DOI: 10.19080/OAJNN.2017.03.555605
9. Stuart CA, Neelon FA, Lebovitz HE (1980) Disordered control of thirst in hypothalamic-pituitary sarcoidosis.N Engl J Med 303(19): 10781082.

10. Ginat DT, Dhillon G, Almast J (2011) Magnetic resonance imaging of neurosarcoidosis. J Clin Imaging Sci 1:15.

11. Bridel C, Courvoisier DS, Vuilleumier N, Lalive PH (2015) Cerebrospinal fluid angiotensin-converting enzyme for diagnosis of neurosarcoidosis. J Neuroimmunol 285: 1-3.

\section{Your next submission with Juniper Publishers} will reach you the below assets

- Quality Editorial service

- Swift Peer Review

- Reprints availability

- E-prints Service

- Manuscript Podcast for convenient understanding

- Global attainment for your research

- Manuscript accessibility in different formats ( Pdf, E-pub, Full Text, Audio)

- Unceasing customer service

Track the below URL for one-step submission https://juniperpublishers.com/online-submission.php 